VO)

27

ISS

3

M R

1984

UMI 

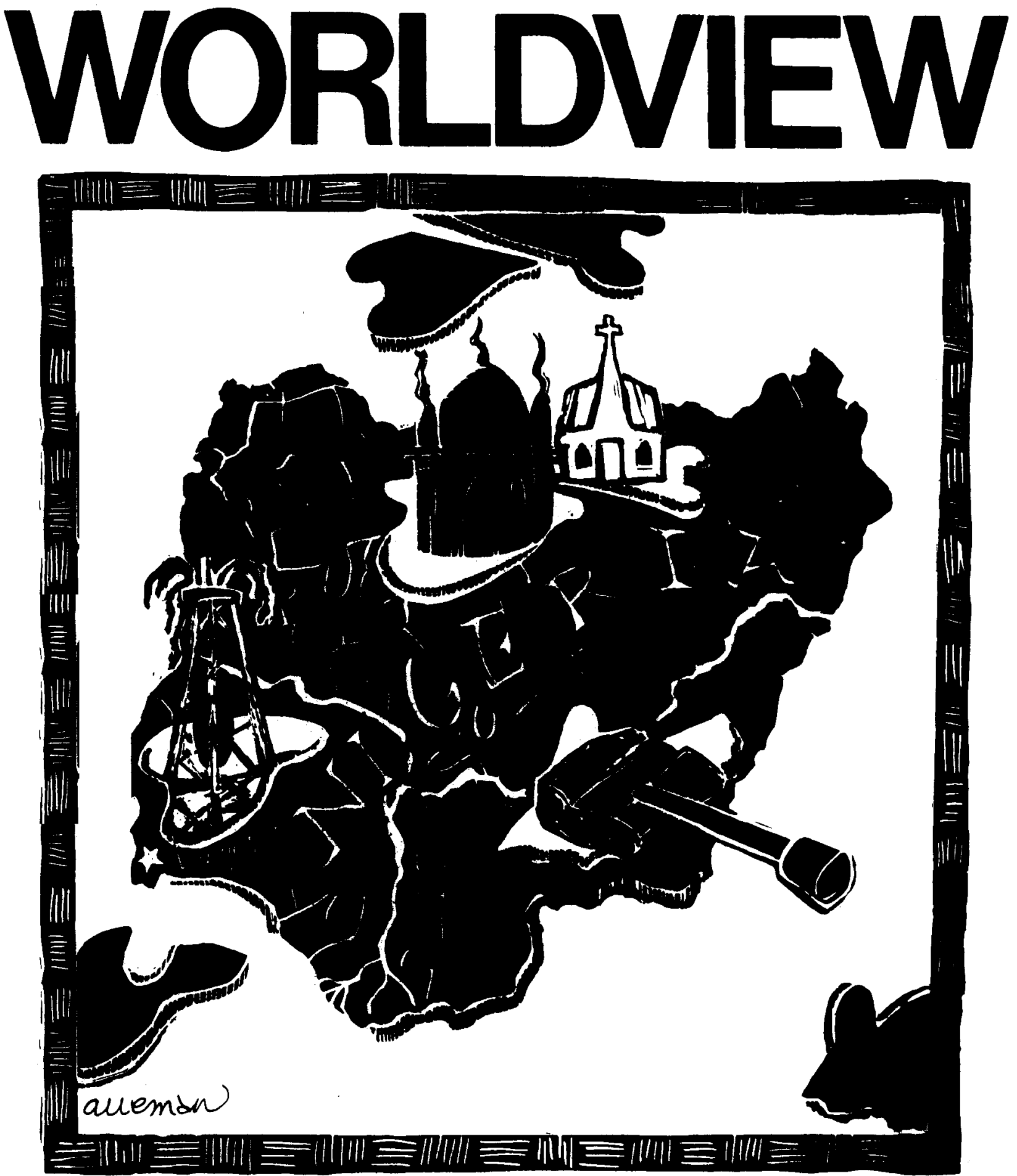

THE UNFINISHED STATE OF NIGERIA

C. S. WHITAKER, JR.

IN DEFENSE OF JAPAN - ROBERT W. BARNETT

EXPORTING NUCLEAR TECHNOLOGY • DANIEL PONEMAN

OUR EMBATTLED EMBASSIES • JOHN B. WOLF

BOOKS: Tina Modotti, Morality \& International Law,

the Indomitable Vatican, Marxism \& Public Health 


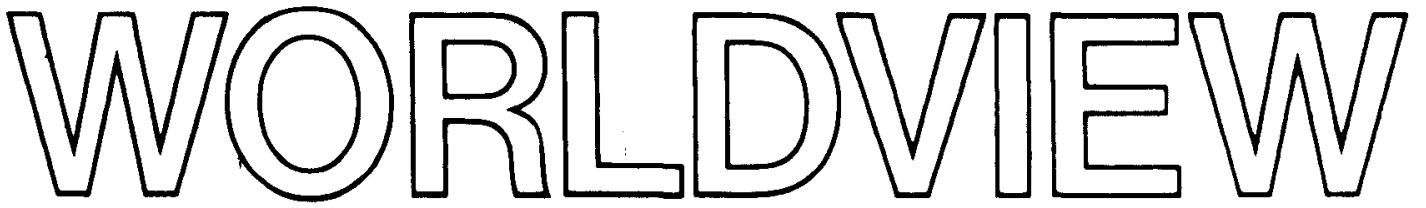

EDITOR

John Tessitore

MANAGING EDITOR

Susan Woolfson

LITERAAY EDITOR

John Becker

CONTRIBUTING EDITORS

Kofi Awoonor

Ross K. Baker

Mark A. Bruzonsky

Benjamin J. Cohen

Stephen S. Fenichell

Albert L. Huebner

Wilson Carey McWilliams

Paul Sigmund

\section{EOITOAIAL INTERNS}

William M. Bosch

Nancy J. Hirsch

\section{DESIGN CONSULTANT}

Robert W. Powell

BUSINESS MANAGER

Eva Becker

\section{EOITORIAL BOARD}

Walter E. Ashley

Robert W. Barnett

Eugene B. Borowitz

Robert F. Drinan, S.J.

Gerald Freund

Robert C. Good

J. Bryan Hehir

Robert J. Myers

Paul Ramsey

Seymour Siegel

Brian Thomas

Kenneth $W$. Thompson

\section{ARTICLES}

The Unfinished State of Nigeria $\quad C$. S. Whitaker, Jr . . 5

In Defense of Japan Robert W. Barnell .......... 9

Embattled Embassies John B. Wolf ..................... 18

The Nuclear Trade Daniel Poneman .................. 21

\section{EXCURSUS}

Comrade Samsonov Goes to War A. Pimenor ........ 13

$\begin{array}{ll}\text { Church \& State Abroad: Squaring Off? Bruce Nichols } & 15\end{array}$

A Five-Power Nuclear Pact Walter C. Clemens, Jr...... 17

\section{COLUMNS}

Under Cover: The State of the President Wilsan Carey Mo William. ... 2

U.N. Watch Stephen S. Fenichell..................... 4

Listening In .......................................... 23

\section{BOOKS}

Law, Morality, and the Relations of States, by Terry Nardın

$$
\text { Robert J. Myers }
$$

The Russian Revolution, by Sheila Fitzpatrick: Lenin and the Problem of Marxist Peasant Revolution, by Esther

Kingston-Mann Thomas $M$. Magstadt

The Power of Rome: The Vatican in the Age of Liberal

Democracies, 1870-1922, by Anthony Rhodes Ralph Buultens

Tina Modotti: A Fragile Life, by Mildred Constantine

$$
\text { Holly Mvers ................. } 28
$$

The Second Sickness, by Howard Waitzkin Albert L. Huebner. . 29

The Peaceable Kingdom, by Stanley Hauerwas

Edward J. Curtin, Jr ..... 30

Briefly Noted ................................ 30

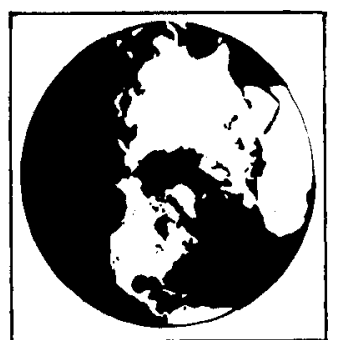

25thANNIVERSARY
WORLDVIEW is oublished monthly by the Council on Religion and International Aftars Subscription-\$19.95 a year; $\mathbf{\$ 3 7}$ for 2 years: $\mathbf{\$ 3}$ for 3 years. Student rate $\$ 9.95$ per year Add $\$ 5.00$ per year for overseas postage. Second-class postage paid at Now York, N $Y$ and al additional entry offices year for over

Opinions expressed in WORLDVIEW are those of the authors and not necessanty of the Council on Rell gion and International Aftairs. CCopyright 1884 Council on Religion and International Aftairs, a publicty supported organization of the type described under sections $509(\mathrm{a})(1)$ and $170(\mathrm{~b})(\mathrm{a})(\mathrm{A})(\mathrm{v})$ of the interne Revenue Code. Unsolicited manuscripts must be accompanied by a stamped. sell-eddressed retum enve 10pe. Letters to the Editor must include signature and address.

Editorial \& Business \& Advertising Offices; 170 E. 64 Street, Now York, N.Y 10021 [212/838-4120] Subscription Office and Change of Address: WORLDVIEW, P.O. Box 1935, Manion, Onio 43305

POSTMASTER: Send address changes to WORLDVIEW, PO Box 1935, Menon, Onwo 43305 